\title{
Project-Based Learning (PjBL): Advantages, Disadvantages, and Solutions to Vocational Education (in Pandemic Era)
}

\author{
Nurul Hidayah ${ }^{1}$, Anisa Puspa Arum², Ari Apriyansa ${ }^{3}$ \\ \{nurul_hidayah@unj.ac.id ${ }^{1}$, aniesapuspa@unj.ac.id², ari_apriyansa@unj.ac.id³ \\ Cosmetology Program, Universitas Negeri Jakarta, Indonesia ${ }^{1,2}$ \\ Education Technology, Universitas Negeri Jakarta, Indonesia ${ }^{3}$
}

\begin{abstract}
This article investigates the Project-Based Learning (PjBL): Advantages, Disadvantages, and Solutions at Vocational Higher Education in Pandemic Era. Vocational Higher Education indicate that students motivation is low especially in online learning to practice their skill content, to accomplish online learning to be effective, the Higher education institutions should support the process, and implement $\mathrm{PjBL}$ to conduct vocational learning, Teacher had to know the advantages and disadvantage of instructional approach, before implement or develop instructional designs. The result of research PjBL of literature study 40 articles, to find out the challenges and benefits of PjBL implementation. The result of research $\mathrm{PjBL}$ from literature study 40 articles are suggesting that advantages the $\mathrm{PjBL}$ approach in online learning is highly recommended for vocational higher education, the student learning outcomes in project-based learning can be improved, besides that students must be able to create knowledge, dan improves their competencies.
\end{abstract}

Keywords: Advantage, Disadvantage, Project-Based Learning (PjBL), Higher Education, Vocational Education

\section{Introduction}

In the era COVID-19, the whole aspects had changes in culture, including the aspect of educational institutions at vocational higher education. Those changes make teachers apply modern learning strategies, although some countries are still adapting in the transition of conventional learning strategies to modern strategies using online platforms to support activities learning. In vocational higher education, online learning is still in doubt, because in vocational learning students are usually provided with skills directly so that students can prepare themselves to become graduates ready to work and have competence. Higher education programs influence students to have knowledge, skills, and practice. [1]. Vocational Education is more oriented to improve students' capabilities in practice to prepare students' future in the workplace, students learn how to improve their performance and skills. Vocational education and training (VET) prepares students to be competent in the workforce [2]. To improve student competencies, it is necessary to apply project-based learning methods of behavior independent students in higher education [3]. Project-based learning is the approach to guide students' created projects [4]. Many Higher Education Institutions are implementing Project-Based Learning 
(PBL) as part of the curriculum [5]. But now, the implementation of PjBL in K-12 education in higher education has been left behind. The online learning process in Higher education in the pandemic era should prepare the platform, content, and tools when applying PjBL to certain that learning is effective [6]. it's because, as long as COVID-19 situation, there has been a surge in interest in online learning [7] so education institutions have to contribute to facilitate students' activities. Higher education institutions have to find out the ways to intensify using online learning, their practices, benefit, and obstacles to online learning [8]. But in vocational higher education indicate that student motivation is low especially in online learning in the pandemic era. although the methods of using technology in vocational education have sought to prevent students from being left behind in their learning [9]. Moreover, learning in Higher Education especially vocational higher education must be able to present learning, using sophisticated learning approaches and tools, before applying learning methods, lecturers must analyze the needs of students and investigate the approach, strategy, and media used in learning and to find out advantages and disadvantage apply design instructional in the class.

\section{Literature Review}

\subsection{Project-Based Learning (PjBL)}

$\mathrm{PjBL}$ is learning that focused on projects, the students construct their own knowledge from collecting information, students can ask questions and provide solutions to existing problems, thus students can access their new information, from teamwork making students closer to classmates. [10] [11] [12]. The PjBL approach refers to an inquiry-based learning method that engages students in knowledge construction and develops real-world products learning [13] [14] [15]. Project-based learning also prepares students to support colaboratif team in difficult situations, beside that also develops skills, and suport time management, and teamwork [16] [17] [5]. PjBL leading teamwork students to collaborate over sustained periods. [18]. The student in team their teamwork is a key part of project-based learning, students must regulate themselves, others, and the group about the project they are spoken [19], [20].

$\mathrm{PjBL}$ is learning that focused on projects, students learn from the process of collecting information to have solutions through asking questions, debating ideas, designing plans, encouraging them to work cooperatively, and leading them to access the information on their own [10] [11] [12]. The PjBL approach refers to an inquiry-based learning method that engages students in knowledge construction and develops real-world products learning [13] [14] [15]. Project-based learning also prepares students for difficult situations, develops skills, time management, and teamwork [16] [17] [5]. PjBL leading teamwork students to collaborate over sustained periods. [18]. Collaboration is a key part of project-based learning, students must regulate themselves, others, and the group about the project they are spoken [19], [20].

Assessing student learning outcomes can be divided into four categories cognitive outcomes, affective, behavior, and product performance student. [21]. To ensure that applying the PBL method is successful, teachers must be supported optimally, especially to facilitating technology in learning, To assessing the progress of students in designing products, then the assessment of students is carried out not only on the final product but also during the learning process to find out process progress of students projects. Hung (2011) The variability in PBL structure can confound findings. Teachers need to make assessment standards that can assess students' 
abilities in aspects of knowledge, skills, and characteristics students of cognitive, affective, and psychomotor [9]. Types of instruments used in PjBL: questionnaires, rubric tests, Scenariobased tests, self-reflection journals. [21] [26] [27] [15] [28].

\subsection{Project-Based Learning (PjBL) in Vocational Education}

Teachers in higher education institutions and universities need to be encouraged to train students in utilizing a Project-Based Learning approach [22]. Applying the PjBL approach should be assimilated within the framework of teacher education as part of the practicum experience [29]. $\mathrm{PjBL}$ allowed students to practice and develop their life skills [27]. In recent years institutions of higher education have been trying to provide students with both hard skills and soft skills [28].

That project-based learning and short-term project-oriented research through technical and vocational higher education can facilitate the process of training and increasing skills [30]. In Vocational education, students of the university were helped by the PBL approach in exploring and sharing information. Vocational education aims to cultivate highly skilled talents to meet the demand of the markets [31]. Project-based courses and teaching focus on a complete work process performed by students in a real work situation [32]. In vocational education, assessment requires students to demonstrate the efficiency of knowledge to provide a proper report of the project [9]. Some studies showed that students' academic knowledge, skills, and motivation were improved after PjBL although students also reported difficulties with PjBL [21].

The PBL approach has enriched both hard and soft skills students [33]. The student's ability in hard skills is an ability to do something example in vocational education in hotel administration [28], general care skills for nursing students [31]. Besides student's ability in soft and hard skills, students, to create a new concepts, and skills of problem-solving and critical thinking. [28] [31] [27] [35], collaboration, and team working skills [16] [5] [28] [31]. There are various ways of organizing and providing vocational education. [36]

Below is presented the findings that have been made by the author based on literature studies of several relevant journals about Project-Based Learning (PjBL): Advantages, Disadvantages, and Solutions to Vocational Education

Table 1.

Summary of selected studies Focus of Project-Based Learning (PjBL) in Vocational Education

\begin{tabular}{llr}
\hline \multicolumn{1}{c}{ Research } & \multicolumn{1}{c}{ Summary in short } & Impact \\
\hline $\begin{array}{l}\text { Cortázar. C, et.al } \\
(2021)\end{array}$ & $\begin{array}{l}\text { That online in project-based learning can improves } \\
\text { critical thinking students it can show from significant } \\
\text { the post-test, }\end{array}$ & Advantages \\
\hline $\begin{array}{l}\text { Lasauskiene, J., \& } \\
\text { Rauduvaite, A. }\end{array}$ & $\begin{array}{l}\text { In higher education institutions, to develop student's } \\
\text { competency need to apply methods of project-based } \\
\text { learning }\end{array}$ & Advantages \\
\hline Žerovnik, et al. & $\begin{array}{l}\text { Project-based learning helps students in their time } \\
\text { management, teamwork, delegation of } \\
\text { responsibilities, prioritizing. }\end{array}$ & \\
\hline $\begin{array}{l}\text { Hasanefendic Sandra, } \\
\text { et.al (2016) }\end{array}$ & $\begin{array}{l}\text { a collaborative between the stakeholders and the } \\
\text { practitioners of technical and vocational higher }\end{array}$ & \\
\hline
\end{tabular}




\begin{tabular}{|c|c|c|}
\hline & $\begin{array}{l}\text { education has benefits when applying PjBL in the } \\
\text { learning process }\end{array}$ & \\
\hline $\begin{array}{l}\text { Lee, Blackwell, } \\
\text { Drake, and Moran } \\
(2014)\end{array}$ & $\begin{array}{l}\text { In institution of education, the progressive } \\
\text { development of } \mathrm{PjBL} \text { in } \mathrm{K}-12 \text { in higher education has } \\
\text { been left behind and have to collaborate with other. }\end{array}$ & Disadvantages \\
\hline Efstratia D (2014) & $\begin{array}{l}\text { There are limitations related to the length of the } \\
\text { project's realization, problems of evaluation appear } \\
\text { and time available in PjBL method. }\end{array}$ & Disadvantages \\
\hline $\begin{array}{l}\text { Kłeczek, R., Hajdas, } \\
\text { M., \& Wrona, S. } \\
(2020)\end{array}$ & $\begin{array}{l}\text { The difficulties were students' inability to create a } \\
\text { shared vision of the project among the stakeholders, } \\
\text { and students' confusion and not knowing what to do } \\
\text { next. }\end{array}$ & Disadvantages \\
\hline $\begin{array}{l}\text { Rambocas and Sastry } \\
\text { (2017) }\end{array}$ & $\begin{array}{l}\text { Implementing PjBL in the introduction of interactive } \\
\text { techniques did not improve the learning outcomes but } \\
\text { improved students' experiences learning. }\end{array}$ & Disadvantages \\
\hline $\begin{array}{l}\text { Noguera, Guerrero- } \\
\text { Roldan, and Maso } \\
\text { (2018) }\end{array}$ & $\begin{array}{l}\text { Those cooperation principles during the project } \\
\text { improve group collaboration but do not improve } \\
\text { student satisfaction. }\end{array}$ & Disadvantages \\
\hline $\begin{array}{l}\text { Grossman, P., Dean, } \\
\text { C. G. P., Kavanagh, } \\
\text { S. S., \& Herrmann, Z. } \\
\text { (2019). }\end{array}$ & $\begin{array}{l}\text { The research show that although the PBL approach is } \\
\text { suitable for improve motivation students, a single } \\
\text { educational practice not suitable all the time }\end{array}$ & Disadvantages \\
\hline $\begin{array}{l}\text { Dina Tsybulsky \& } \\
\text { Yulia Muchnik- } \\
\text { Rozanov (2019) }\end{array}$ & $\begin{array}{l}\text { Student-teachers have difficulties while implementing } \\
\text { PjBL, because of PjBL process, took up more time } \\
\text { than traditional teaching }\end{array}$ & Disadvantages \\
\hline Qianling Li (2021) & $\begin{array}{l}\text { From the result research show that the goal of talents } \\
\text { training in vocational education is shifted from } \\
\text { knowledge oriented to ability and literacy oriented. }\end{array}$ & Solution \\
\hline $\begin{array}{l}\text { Pengyue Guo, et all. } \\
(2020)\end{array}$ & $\begin{array}{l}\text { Students' outcome learning can were measured by } \\
\text { questionnaires, interviews, observation, and self- } \\
\text { reflection journals were their implementa PjBL } \\
\text { method in learning process }\end{array}$ & Solution \\
\hline $\begin{array}{l}\text { Douladeli Efstratia, } \\
\text { (2014) }\end{array}$ & $\begin{array}{l}\text { To recommended to integrate project-based learning } \\
\text { with modern learning }\end{array}$ & Solution \\
\hline $\begin{array}{l}\text { Culclasure, B. T, } \\
\text { Longest, K. C. \& } \\
\text { Terry, T. M. (2019) }\end{array}$ & $\begin{array}{l}\text { The challenges and opportunities applying PjBL can } \\
\text { be properly identified, and adequate preparation. }\end{array}$ & Solution \\
\hline $\begin{array}{l}\text { Mohammed } \\
\text { Abdullatif Almulla } \\
\text { (2020) }\end{array}$ & $\begin{array}{l}\text { Higher education needs to encourage teachers } \\
\text { implemented PBL approach, to improve student } \\
\text { achievements. }\end{array}$ & Solution \\
\hline (Pengyue Guo, 2020) & $\begin{array}{l}\text { For futures studies, teacher should find out about } \\
\text { performance of students influence final products. }\end{array}$ & Solution \\
\hline $\begin{array}{l}\text { Syahrila, Rahmat } \\
\text { Azis Nabawi Febri } \\
\text { Prasetyac } \\
(2020)\end{array}$ & $\begin{array}{l}\text { The application media on the PjBL model improving } \\
\text { student competence }\end{array}$ & Solution \\
\hline
\end{tabular}

\section{Discussion}

The hypothesis in this article is that Project-Based Learning has advantages and disadvantages in the learning process and results. Beneficial aspects of student learning have proven that PjBL improves content knowledge and competencies [3][27], skills [15][31][34], motivation [31], and 
product quality [21]. students' perception of the PBL approach is positive, to improve their academic performance [23] [24]. Project-based learning (PjBL) is can be implementation in various online collaborative learning environments [36].

However, there are some disadvantages to the implementation Project-based learning, a dilemma applying PjBL for teachers, is when the students tend to treat even passing comments or suggestions from their teacher [37]. Although implementing PjBL is suitable for teachers and students, they know that difficulties while implementing PjBL is not always improve the learning outcomes students, and when the collaborative process took up more time than traditional teaching there are limitations related to the length of the project's realization, even problems of evaluation appear, and although project-based learning can use modern teaching by utilizing platforms for online learning. Universities need to give solutions in PjBL approach especially in vocational higher education in online learning, the students must actively participate in building ideas, constructing information, creating a space where the lecture is stimulated to experiment with an assessment of online instruments, ensuring there are video and audio ports and need to make clear assessment instruments on projects made by students.

To certain learning processes effective in vocational higher education, lectures should apply $\mathrm{PjBL}$ approach to collaborate with online learning. That online project-based learning can improve the capability of students exactly in critical thinking [38], and when evaluating students in learning processes must be supported with clear standard assessment instruments so that student learning motivation does not decrease. Solutions for the PjBL approach in vocational higher education are highly recommended for use by teachers and students. Future efforts applying PjBL should also reflect the opinions of teachers and stakeholders in the academic environment [22] and must be supported by the academic institutions. For future research the application of learning of instructional media based on the PjBL approach must improving student competence [39]. The project-based learning approach has much advantage effect on students' academic achievement [40].

\section{Conclusions}

Results showed that PjBL approach has many benefits in the learning process and outcome, to develop and implement PjBL, the method has to integrate the modern tool in online learning in the pandemic era. The advantage of PjBL is increased students' knowledge, motivation, skills, and product quality, also improving competencies of students in vocational higher education. although the PjBL approach has benefits, the application PjBL has obstacles, so in the future, to achieve the instructional goal more effectively in vocational higher education, the lectures have to develop and create assignment instruments standards for certain the student.

\section{Acknowledgment}

The authors to acknowledge for Faculty Of Engineering, Universitas Negeri Jakarta, Indonesia, 2021.

\section{References}

[1] Maria Esther Oswald-Egg, Ursula Renold, (2021). No experience, no employment: The effect of vocational education and training work experience on labor market outcomes after higher education, Economics of Education Review, Volume 80, 102065, ISSN 0272-7757, https://doi.org/10.1016/j.econedurev.2020.102065.

[2] Schwendimann, B. A., De Wever, B., Prof, R. H., \& Cattaneo, A. A. P. (2018). The state-of-the-art of collaborative technologies for initial vocational education: A systematic literature review. 
International Journal for Research in Vocational Education and Training, 5(1), 19-41. https://doi.org/10.13152/IJRVET.5.1.2

[3] Lasauskiene, J., \& Rauduvaite, A. (2015). Project-Based Learning at University: Teaching Experiences of Lecturers. Procedia - Social and Behavioral Sciences, 197(February), 788-792. https://doi.org/10.1016/j.sbspro.2015.07.182

[4] Krajcik, J. S., \& Shin, N. (n.d.). Project-Based Learning. The Cambridge Handbook of the Learning Sciences, 275-297. doi:10.1017/cbo9781139519526.018

[5] Žerovnik, Alenka \& Nančovska Šerbec, Irena. (2021). Project-Based Learning in Higher Education. 10.1007/978-981-16-2082-9_3.

[6] Kukulska-Hulme, A. (2012). How should the higher education workforce adapt to advancements in technology for teaching and learning? The Internet and Higher Education, 15(4), 247-254. doi:10.1016/j.iheduc.2011.12.002

[7] Heinrich Peters, Andrew Kyngdon, David Stillwell, (2021). Construction and validation of a gamebased intelligence assessment in Minecraft, Computers in Human Behavior, Volume 119, 106701, https://doi.org/10.1016/j.chb.2021.106701.

[8] Alhawsawi, S., \& Jawhar, S. S. (2021). Negotiating pedagogical positions in higher education during COVID-19 pandemic: teacher's narratives. Heliyon, 7(6), e07158. https://doi.org/10.1016/j.heliyon.2021.e07158

[9] Mustapa, M. A. S., Ibrahim, M., \& Yusoff, A. (2015). Engaging Vocational College Students through Blended Learning: Improving Class Attendance and Participation. Procedia - Social and Behavioral Sciences, 204, 127-135. doi:10.1016/j.sbspro.2015.08.125

[10] Kim, Booyuel; Lee, Ju-Ho; Choi, Junghee (2019), "Data for: How does Learner-Centered Education affect Teacher Self-Efficacy? The case of Project-Based Learning in South Korea”, Mendeley Data, V1, doi: 10.17632/cfdtmrrh4m.1

[11] English, M. C., \& Kitsantas, A. (2013). Supporting Student Self-Regulated Learning in Problemand Project-Based Learning. Interdisciplinary Journal of Problem-Based Learning, 7(2). https://doi.org/10.7771/1541-5015.1339

[12] Chiang, C. L., \& Lee, H. (2016). The Effect of Project-Based Learning on Learning Motivation and Problem-Solving Ability of Vocational High School Students. International Journal of Information and Education Technology, 6(9), 709-712. https://doi.org/10.7763/ijiet.2016.v6.779

[13] Lampert, M., Franke, M. L., Kazemi, E., Ghousseini, H., Turrou, A. C., Beasley, H., Crowe, K. (2013). Keeping it complex: Using rehearsals to support novice teacher learning of ambitious teaching. Journal of Teacher Education, 64(3), 226-243.

[14] Wiek, Arnim \& Xiong, Angela \& Brundiers, Katja \& Van der Leeuw, Sander. (2014). Integrating problem- and project-based learning into sustainability programs. International Journal of Sustainability in Higher Education. 15. 431-449. 10.1108/IJSHE-02-2013-0013.

[15] Brassler, M., \& Dettmers, J. (2017). How to Enhance Interdisciplinary CompetenceInterdisciplinary Problem-Based Learning versus Interdisciplinary Project-Based Learning. Interdisciplinary Journal of Problem-Based Learning, 11(2). https://doi.org/10.7771/15415015.1686

[16] Häkkinen, P., Järvelä, S., Mäkitalo-Siegl, K., Ahonen, A., Näykki, P., Valtonen, T. (2017). Preparing teacher-students for twenty-first-century learning practices (PREP 21): A framework for enhancing collaborative problem-solving and strategic learning skills. Teachers and Teaching, 23(1), 25-41.

[17] Kokotsaki, D., Menzies, V., \& Wiggins, A. (2016). Project-based learning: A review of the literature. Improving Schools, 19(3), 267-277. doi:10.1177/1365480216659733

[18] Grossman, P., Dean, C. G. P., Kavanagh, S. S., \& Herrmann, Z. (2019). Preparing teachers for $\begin{array}{llll}\text { project-based teaching. Phi Delta } & \text { Kappan, } & \text { 100(7), }\end{array}$ https://doi.org/10.1177/0031721719841338

[19] Virtue, E. E., \& Hinnant-Crawford, B. N. (2019). "We're doing things that are meaningful": Student Perspectives of Project-based Learning Across the Disciplines. Interdisciplinary Journal of Problem Based Learning, 13(2). https://doi.org/10.7771/1541-5015.1809

[20] P.H. Winne, A.F. Hadwin, and N.E. Perry C.E. Hmelo-Silver, C.A. Chinn, C. Chan, A.M. O'Donnel (Eds.), (2013). International handbook of collaborative learning, Routledge, New York, pp. 462-479 
[21] Guo, P., Saab, N., Post, L. S., \& Admiraal, W. (2020). A review of project-based learning in higher education: Student outcomes and measures. International Journal of Educational Research, 102(April), 101586. https://doi.org/10.1016/j.ijer.2020.101586

[22] Almulla, Mohammed. (2020). The Effectiveness of the Project-Based Learning (PBL) Approach as a Way to Engage Students in Learning. SAGE Open. 10. 215824402093870. $10.1177 / 2158244020938702$.

[23] Basilotta Gómez-Pablos, Verónica \& Martín Del Pozo, Marta \& García-Valcárcel, Ana. (2017). Project-based learning (PBL) through the incorporation of digital technologies: An evaluation based on the experience of serving teachers. Computers in Human Behavior. 68. 501-512. 10.1016/j.chb.2016.11.056.

[24] Bilbao, J., Varela, C., Rebollar, C., Bravo, E., \& García, O. (2018). Selecting assessments for problem-based learning. International Journal of Education and Learning Systems, 3, 129-133

[25] Bridges, S. M. (2019). The Interdisciplinary Journal of Problem-based Learning Special Issue: Unpacking The Role Of Assessment In Problem- And Project-Based Learning The Triple Jump in Problem-Based Learning : Unpacking Principles and Practices in Designing Assessment for Curr, 13(2), 9-13.

[26] Rodríguez. Jacobo, Simavilla. Ana Laverón, Del Cura. Juan M, Ezquerro. José M, Lapuerta. Victoria, Gracia. Marta Cordero (2015). Project Based Learning experiences in the space engineering education at Technical University of Madrid, Advances in Space Research, Vol 56, 7, 1319-1330, https://doi.org/10.1016/j.asr.2015.07.003.

[27] Wurdinger, S., \& Qureshi, M. (2014). Enhancing College Students' Life Skills through ProjectBased Learning. Innovative Higher Education, 40(3), 279-286. doi:10.1007/s10755-014-9314-3

[28] Vogler, Jane \& Thompson, Penny \& Davis, David \& Mayfield, Blayne \& Finley, Patrick \& Yasseri, Dar. (2018). The hard work of soft skills: augmenting the project-based learning experience with interdisciplinary teamwork. Instructional Science. 46. 10.1007/s11251-017-9438-9.

[29] Tsybulsky, D., \& Muchnik-Rozanov, Y. (2019). The development of student-teachers professional identity while team-teaching science classes using a project-based learning approach: A multi-level analysis. Teaching and Teacher Education, 79, 48-59. https://doi.org/10.1016/j.tate.2018.12.006

[30] Hasanefendic, S., Heitor, M., \& Horta, H. (2016). Training students for new jobs: The role of technical and vocational higher education and implications for science policy in Portugal. Technological Forecasting and Social Change, 113, 328-340. doi:10.1016/j.techfore.2015.12.005

[31] Wu, X., Chen, Y., Zhang, J., \& Wang, Y. (2012). On Improving Higher Vocational College Education Quality Assessment. Physics Procedia, 33, 1128-1132. doi:10.1016/j.phpro.2012.05.185

[32] Qianling Li, (2021). Analysis and practice on the training of key ability of students majoring in electronic information in higher vocational education, Procedia Computer Science, Vol 183, 791 793, doi.org/10.1016/j.procs.2021.02.130.

[33] Kuppuswamy, R., \& Mhakure, D. (2020). Project-based learning in an engineering-design course Developing mechanical- engineering graduates for the world of work. Procedia CIRP, 91, 565-570. https://doi.org/10.1016/j.procir.2020.02.215

[34] Sabura Banu, U. (2020). Technical skill up-gradation by project-based learning and exposing to state-of-art technologies. Procedia Computer Science, 172, 950-953. https://doi.org/10.1016/j.procs.2020.05.137

[35] Culclasure, B. T., Longest, K. C., \& Terry, T. M. (2019). Project-Based Learning (Pjbl) in Three Southeastern Public Schools: Academic, Behavioral, and Social-Emotional Outcomes. Interdisciplinary Journal of Problem-Based Learning, 13(2). https://doi.org/10.7771/15415015.1842

[36] M. Inoue, Y. Suhara, M. Ichikawa, X. Chen and T. Wagatsuma, "Planning and Implementation of Large-Scale Online Project-Based Learning and Flipped Classes," 2020 IEEE International Conference on Teaching, Assessment, and Learning for Engineering (TALE), 2020, pp. 918-921, doi: 10.1109/TALE48869.2020.9368494.

[37] Mark J.W. Lee, Sasha Nikolic, Christian H. Ritz, 9 - Supporting the conceptualization of student innovation projects through peer and expert feedback on virtual pitches, Editor(s): Sharmila Pixy Ferris, Hilary Wilder, Unplugging the Classroom, Chandos Publishing, 
(2017), Pages 119-135, ISBN 9780081020357. https://doi.org/10.1016/B978-0-08102035-7.00009-6.

[38] Chen, C.H. \& Yang, Y.C. (2019). Revisiting the effects of project-based learning on students' academic achievement: A meta-analysis investigating moderators. Educational Research Review, 26(1), 71-81. Elsevier Ltd. Retrieved August 20, 2021, from https://www.learntechlib.org/p/207141/.

[39] Cortázar. C, Nussbaum. M, Harcha. J, Alvares. D, López. F, Goñi. J, Cabezas. V (2021). Promoting critical thinking in an online, project-based course. Computers in Human Behavior. Vol 119, June 2021, 106705. https://doi.org/10.1016/j.chb.2021.106705.

[40] Syahril, Nabawi, R. A., \& Prasetya, F. (2020). The instructional media development of mechanical drawing course based on project-based learning. International Journal of Innovation, Creativity, and Change, 11(4), 309-325.

[41] Fuller, A., (2015). Vocational Education. In: James D. Wright (editor-in-chief), International Encyclopedia of the Social \& Behavioral Sciences, 2nd edition, Vol25. Oxford: Elsevier. pp. 232 238.ISBN: 9780080970868. Elsevier Ltd. 